\title{
COMMODITY MARKET MATH MODELS
}

УДК 658

Boris V. Mednikov,

Department Head «SB-studio», Penza

E-mail:borismednikov@gmail.com

\section{Vladimir I. Mednikov,}

Specialist J.-s.Co. «MMS», Moscow

E-mail: vladimmednikov@gmail.com

\section{Stepan V. Mednikov,}

Team Leader J.-s. Co. "VympelKom», Penza

E-mail: smednikov@gmail.com

The article describes enterprise math models, its interactions with environment in commodity market and quantitative conditions for its success and the crisis in such kind of interaction. Showed: the number of commodity market successful participants should be certain, regardless of market size; any size commodity market, including monopolistic, is as successful as producers' average activity dynamics is balanced with consumers' average activity dynamics.

Keywords: model, enterprise, market, crisis, environment.

Борис Владимирович Медников, Начальник отдела, «SB-studio», Пенза Эл. почта: borismednikov@gmail.com

Владимир Иванович Медников, Специалист, ОАО «МMC», Москва Эл. почта: vladimmednikov@gmail.com

Степан Владимирович Медников, Руководитель группы, ОАО «ВымпелКом», Пенза

Эл. почта: smednikov@gmail.com

\section{МАТЕМАТИЧЕСКИЕ МОДЕЛИ TОВАРНОГО РЫНКА}

Статья описывает математические модели предприятия, их взаимодействия с внешней средой и количественные условия их успеха и кризиса в этом виде взаимодействия. Показано: число успешных участников товарного рынка должно быть определенным независимо от его размера; товарный рынок настолько успешный, насколько динамика производителей сбалансирована с динамикой потребителей.

Ключевые слова: модель, предприятие, рынок, кризис, внешняя среда.

\section{Introduction}

Any company creation (manufacturing, defense, institutions, etc.) aims to satisfy the needs of its environment in company's assignment function. The satisfaction carries out by reacting company with environment by means of resources exchange. We assumed that any enterprises' external environment is a collection of similar enterprises, businesses, and users, subjects of influences. The specifics of the market (commodity, securities, etc..) is characterized by alternating ups and downs in this exchange [1], as determined by subjective needs of market participants. One of the foundations of our work goal-setting has become observation: if all the companies of a region have low activity dynamics, then the region is characterized analogously.

\section{Discuss Problem}

At the present stage of the protection theory development we concentrated meticulous attention to search for a commodity market math model in the security aspects of enterprise management. Modern practice [2] established market models, which couldn't answer questions as follows what parameters participants should be characterized for their safe interaction, how many members should be in the market, etc. Up till now we proceed our point of view that such instruments as queuing theory, scheduling theory and game theory use "pure", i.e. protected, enterprises models. Owing to what these instruments are not applicable for our tasks.

Formation of an enterprise math model is obviously required weather the selection of well-known math apparatus or creates a new one. Unfortunately, the known academic publications [3], [4] and others [5], show that the overwhelming majority of the concepts, tools for description an interactions with internal or external environment, resources protection, criteria ratings and so on reflect the applied, but not formal enterprises' character and are hidden from the devisers by means of literary delights or author's wordings.

For the purpose of the commodity market math model construction we sieved many publications among which we selected three the most appropriate enterprise models: 1 - some land register with the capital-intensive industries [6], where disruption is accompanied the damage to the working people, environment and the economy of the region; 2 - the dependence of the enterprise activity main indicator $X$ from some internal potential $F x$ in form of function $f$ : " $X=f(F x)$ ", where $X$ represents manufacturing product; $F x$ represents "some factor of manufacturing" [7]; 3 - Management system "Balanced ScoreCard" [8].

The model 1 uses the enterprise territory as a parameter to describe its activity and, figuratively, does not know what to change in the company internal processes in order to achieve its success in the market. The model 2, just like the first, includes no information about the environment, however, in contrast to the first, allows utmost for successful activity. The model 3 is closest to proposed us. But four indicators, in our opinion, aren't enough to achieve the purpose of the stage.

In the light of the above, we have proposed a cognitive enterprise model, which includes its external environment (Figure 1) [9]. As practice showed, this structure is found to be suitable for modeling teacher, religious clashes, mobile combat units, others.

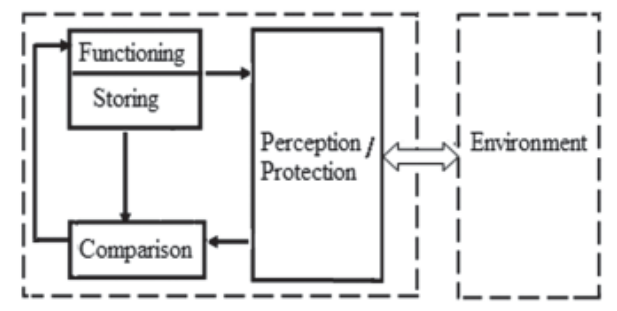

Fig.1. Enterprises cognitive model 
Example: some religious group, if any, is "Functioning" (see pertinent modulus on Figure 1) in other religious congregation vicinity (modulus "Environment"); during some period of time the group's leaders established and clarified (modulus "Comparison") that their religious principles, canons or traditions (modulus "Storing") were subjected to congregation representatives insults; if the group haven't formed the rules concerning similar cases, the most aggressive this group representatives can organize any clashes against other congregation, i.e. religious clashes; otherwise these clashes won't occur.

In contrast to known approaches we avowed reasonable to use enterprise production "function" as the indicator for its activity description. Because the "function" means mutually and uniquely connects facts of "product" manufacturing and the facts of the complementary resources usage for this manufacturing. In contrast to known approaches our approach consists of multilevel decomposition of enterprise function and recourse, its environment and their interactions decompositions. Because hierarchy structure of all enterprise management systems wasn't canceled so far we guess the better any enterprise is structured the less personal we need for its functions execution on every level. Our structuring method made it possible to abandon any enterprise industrial classification (defense, educational, social, etc.) and with that to describe it completely. In other words, our approach to math models construction bases on enterprise function and seven complementary resource components multilevel decomposition (Figure 2).

Our practice shows that different participants' decompositions usually have up to 4 levels (profiles) "Branch", "Assignment", "Functional" and "Atomic" (see Figure 2). Example, agricultural enterprise has two levels in decomposition. The lowest level "Atomic" represents prime processes, that detached human is performing; herewith this human is an elementary accounting unit of participant's human resource.

Every participant function on Figure 2 on every level has an own amount of "manufacturing cycle" $(M C)$. Dur- ing $M C$ participant creates or manufactures some part of its activity main indicator in real or in value terms. Thereby enterprise is replaced by its own equal multilevel internal environment which creates (manufactures) activity main indicator or its component. We have found the rational fractions are the most appropriate instrument to realize "function" because by the fraction usage we could reproduce such the most difficult enterprise activity indicator as inertia.

We used enterprise (market participant) production function $f(s)$ as an indicator for its modeling. The function $f(s)$ mutually and uniquely connects facts of «product» manufacturing and the facts of the complementary resources usage for this manufacturing.

$f(s)$ is a fraction, the numerator represents the Laplace image of the sequence of facts commodity output production $p_{i}$ during some accounting interval, and the denominator - the Laplace image of the sequence of the facts complementary resource $r_{i}$ usage for manufacturing $p_{i}$ during the same interval:

$$
\begin{gathered}
f(s)= \\
=\frac{p_{0}+p_{1} s^{1}+p_{2} s^{2}+\ldots+p_{n} s^{n}}{\left[r_{0}\right]+\left[r_{1}\right] s^{1}+\left[r_{2}\right] s^{2}+\ldots+\left[r_{n}\right] s^{n}}+ \\
+\varphi(s)
\end{gathered}
$$

where $f(s)$ - production function on some level; $p_{i}$ - facts of main activity indicator realization in $i$-th moment of time; $n$ - the dimension of the accounting time interval $n \Delta t ; \Delta t$ - elementary interval of time; $r_{i}$ - facts of internal resource usage in order to create $p_{i} ; r_{i}$ is represented by rectangular matrix $[7 \times n]$, where 7 - the number of rows of the matrix which equal number of resource components $r_{i}$ (Fig. 4): environment (env.), finance (mo.), communicative (co.), technical (te.), human (hu.), time (ti.), protection (pr.); $s=R e+j I m ; R e-$ abscissa of absolute convergence; Re and Im - arguments (in this case orthonormal basis $\exp (j n \Delta t / T)$ of Laplace transform was used); $\varphi(s)$ - Laplace transform of participant activity initial conditions. Example 1: for $i$-th moment of time we have model $f(s)=p_{i}(s) /\left[r_{i}(s)\right]$ on some level of decomposition; example 2: finance (mo.) resource component can be represented such habitual indicators as capital productivity, leverage ratio, the ratio of debt to equity, etc.

In compare with named above enterprise math models our model $f(s)$ is unique because it quantitatively defines the enterprise multilevel complementary resources and the parameters of internal processes, is scalable, allows for non-stationarity of these

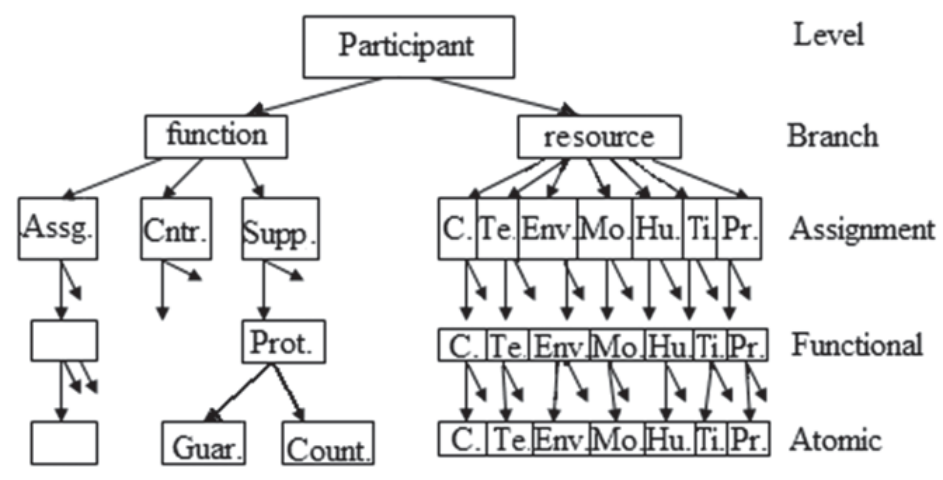

Fig.2. Four levels of participant functions and resources decomposition, where denoted functions: Assg. - assignment function; Cntr. - control; Supp. supporting; Prot. - protection; Guar. - guard; Coun. - counteract, and denoted resources: C. - communicative; Te. - technical; Env. - enterprise internal environment; Mo. - financial (money); Hu. - human resource; Ti. - resource of time; Pr. - protection

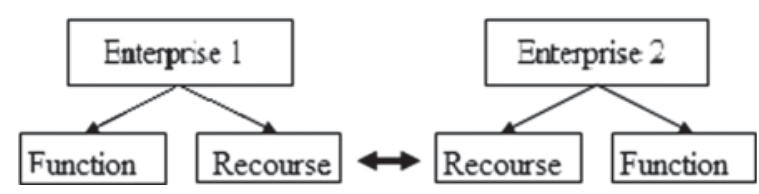

Fig.3. Interaction in elementary market 


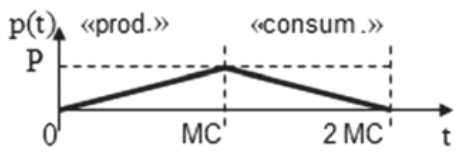

Fig.4. Dynamic condition of enterprise success on the market

parameters, reproduces the processes' inertia, does not have the industry specificity, and in comparison with the these models is more adequate to real enterprises, including external ones. In addition, $f(s)$ ensures the transparency of our enterprise activity, simplifies the search for the causes of "unsatisfactory" its main indicator behavior, and the means to search these causes [10]. Besides, our model opened the ways for the modern information technologies application - GIS, recourse accounting, others. Owing to what it is distinguished significantly from named models.

One of the parameters that uniquely describes any enterprise is its «manufacturing cycle» $(M C)$ - enterprise $M C_{\text {ent. }}$ or environment $M C_{\text {env. }}$ The scope of $M C$ in its broadest sense comprises such characteristics as «productivity per shift», «production time per unit of output», «production cycle» or other more complex, which reflect the enterprise technological, organizational, industry-specific features and linked to the usual periods of time «seconds», ..., «year». In the general case $M C$ is the time interval of manufacture, sale, etc. per unit, and is approximately equal to the sum of the durations of technological operations execution plus accounting and reporting procedures execution. Using $M C$, we constructed the commodity market math models.

\section{Commodity Market Math Models}

Model of elementary commodity market is represented by one name of product and the resources interaction of one manufacturer (enterprise 1) and one customer (enterprise 2) (Figure 3); herewith the company as a whole, but not his subdivision, is a market player. There is no doubt the assertion: elementary market is successful if it «does not prevent» Enterprise 1 ("prod." on Figure 4) to manu- facture the production, for example, in the amount of $P$ during $M C$, and Enterprise 2 ("consum.") to consume this amount $P$ during the next $M C$.

The vector form of this condition

$$
(\overrightarrow{P / M C})_{\text {prod. }}=(\overrightarrow{P / M C})_{\text {consum. }}
$$

takes into account the purpose of participants' interaction in market. This form equal to conjugate the activity vectors both "prod." and "consum." (Figure 5) relatively axis " $t$ ".

We have found [9] both enterprises 1 and 2 have the same activity dynamics decline which provides the formal condition $M C_{1}=M C_{2}$ or in terms of the accounting interval provides $n \Delta t / M C_{1}=n \Delta t / M C_{2}$ (here scale $P=1$ ). This condition in everyday language is interpreted as follows: products in the amount of $P_{1}=n \Delta t / M C_{1}=P_{2}=$ $=n \Delta t / M C_{2}$ are produced and consumed within the same periods of time. Practice shows that $M C_{1}$ is more or less $M C_{2} k$ times, owing to what the general condition of the successful interaction between enterprises 1 and 2 (read: economically secure) on the elementary market provides equality $M C_{1}=k M C_{2}$ or, in terms of the accounting interval, $n \Delta t / M C_{1}=k n \Delta t / M C_{2}$.

Obtained conditions are interesting that the value of $k$ in the equality represents an average enterprise's parameter that reflects the real market volatility, i.e. boom-bust cycles of consumption [1]. Furthermore these conditions are of interest because the value $n \Delta t / M C_{1}$ is numerically equal to the annual ( $n \Delta t=1$ year) of $Q$ output in the Cobb-Douglas equations [9].

We clarified the crisis model [9]. The enterprise 1 as market participant will be in danger during some manufacturing cycles $M C_{1}$ when it «did not have time to gain enough money» from its goods sale by enterprise 2. Economically it means the enterprise main indicator deterioration and mathematically that slope of «Effective dynamics» of «Manufacturer» is gradually decline from the $M C$ to $M C$ (Figure 6), i.e. gradual interaction «dis-harmony» between market participants.

The condition of this danger for the enterprise 1 has the form: $M C_{1}<M C_{2}$ («enterprise 1 quickly

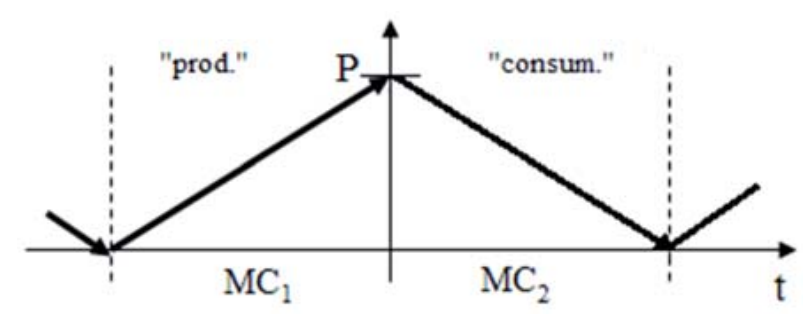

Fig.5. Vector form of enterprise success condition for elementary commodity market

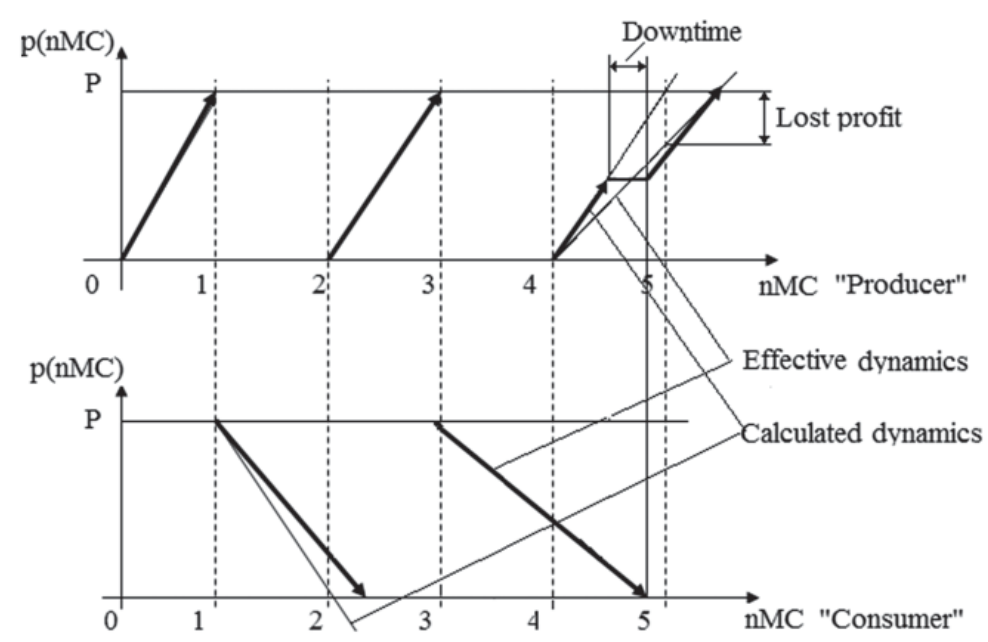

Fig.6. Interaction «dis-harmony» in commodity market 
produces goods, but enterprise 2 consumes it slowly and gives the money back slowly too»). Similar danger condition for enterprise 2: the slope of its effective dynamics is provided if $M C_{1}>M C_{2}$ («enterprise 1 slowly produces goods and enterprise 2 consumes it quickly and gives the money back quickly too»). Practice has shown that the duration of the recession has an inverse dependence on $n \Delta t / M C$, i.e. on number of enterprise manufacturing cycles per year.

Enterprise Management corrects activity recession successfully if both the lack of any resource component no exceeds some threshold value («risk» [9]) and no postpones such legal means reversing the decline as reduction costs of production, remove to new markets, loans and debt restructuring, marketing orientation changes. We found the less importance of different enterprise resource components $\left[r_{i}\right]$ for its activity the more successful this correction of the recession [9].

The crisis as the most dangerous state of the enterprise 1 operations occurs when both conditions take place: the shortage of some resource components or components' damage exceeds the threshold value («threat» [11]) for a long time (circa from $2 M C$ to $2,000 M C$ and depends on branch) and if the enterprise Management has coincidently applied means of reversing the decline (see above) unsuccessfully.

The basic mean for enterprise crisis protection since Adam Smith («wild market»), and to this day remains a capital. The capital concentration in hands of the small number of individuals has been sustained [12]. Such concentration becomes the main factor in the formation of interests, which are changing and, as a rule, no coincide with the enterprises' interests, and, in particular, the instability factor of investment «climate». Such concentration makes lopsided changes in everybody's life planning. This is manifested in pursuit of capital which is meaningless because nobody knows scale, duration, or depth of upcoming crises. Our attempts are directed to devise the ways to overcome these conditions.

Our approach made it possible to construct math models of more com-

\begin{tabular}{|c|c|c|}
\hline \multicolumn{3}{|c|}{ Spreadsheet } \\
\hline $\begin{array}{l}\text { Market } \\
\text { scale }\end{array}$ & Math model & $\begin{array}{c}\text { Quantitative determina- } \\
\text { tion }\end{array}$ \\
\hline Elementary. & $P_{\text {manuf. }} / n \mathrm{D}$ & $\begin{array}{l}\text { Commodity - single; } \\
\text { Manufacturer - single; } \\
\text { Consumer - single. }\end{array}$ \\
\hline Simple. & $P_{\text {manuf. }} / n \Delta t=(1 / I) \sum_{i=2}^{I} P_{\text {cons. } i} /(n \Delta t)_{i}$ & $\begin{array}{l}\text { Commodity - single; } \\
\text { Manufacturer - single; } \\
\text { Consumers - I, } i \in[2, I] \text {. } \\
\text { Note: If " } I \text { " equal quantity } \\
\text { of all consumers, the mar- } \\
\text { ket is monopolistic. }\end{array}$ \\
\hline $\begin{array}{l}\text { Note: } \\
\text { international } \\
\text { monopolistic } \\
\text { market. }\end{array}$ & $P_{\text {manuf. }} / n \Delta t=(1 / I) \sum_{j=2}^{J} \sum_{i=2}^{I} P_{\text {cons.i }} /(n \Delta t)_{i}$ & $\begin{array}{l}\text { Commodity - single; } \\
\text { Manufacturer - single; } \\
\text { Consumers - I, } i \in[2, I] \\
I \text { - quantity of all consum- } \\
\text { ers of country; } \\
\text { Quantity of country- } \\
\text { to-consumer - } j ; j \in[2, J] .\end{array}$ \\
\hline Complex. & $\sum_{z=2}^{Z} P_{\text {manuf. } z} /(n \Delta t)_{z}=(1 / I) \sum_{i=2}^{I} P_{\text {cons. } i} /(n \Delta t)_{i}$ & $\begin{array}{l}\text { Commodity }- \text { single; } \\
\text { Manufacturers }-z \text {, } \\
z \in[2, Z] \text {; } \\
\text { Consumers }-I, i \in[2, I]\end{array}$ \\
\hline Real. & $\sum_{m=2}^{M} \sum_{z=2}^{Z} P_{\text {manuf. } . z} /(n \Delta t)_{z}=(1 / I) \sum_{i=2}^{I} P_{\text {cons. } i} /(n \Delta t)_{i}$ & $\begin{array}{l}\text { Commodities }-m, \\
m \in[2, M] \\
\text { Manufacturers }-z \\
z \in[2, Z] \text {; } \\
\text { Consumers }-I, i \in[2, I]\end{array}$ \\
\hline
\end{tabular}

plex commodity market (see Spreadsheet).

For instance simple market, which consists of one manufacturer and three different customers, should be successful if manufacturer activity dynamics equal average dynamics of these customers. We found similar condition is right for the other market scale. Specifically the success on commodity market is based on accounting every participant's activity dynamics which averaged over the full number (i.e. I) market participants. If we work with monopolistic international market we must take into account all countries (i.e. $J$ ) participated in the market. The latter suggests the number of successful participants should be certain regardless of market size. Besides, any size commodity market, including monopolistic, is as successful as producers' average activity dynamics is balanced with consumers' average activity dynamics.

The crises history study shows that economic instruments couldn't predict neither the commodity market crisis parameters, overcome it, nor prevent its detrimental influence on popular majority. We guess that showed commod- ity market models shouldn't be premature and bear possibilities to develop contemporary economic instruments.

\section{Conclusion}

The article contains enterprise math model, successful commodity market math models, and market participants' crisis conditions. Our results show: manufacturers' total dynamics must be balanced with consumers' total dynamics for their success in this market regardless the market size; any size commodity market, including monopolistic, is as successful as producers' average activity dynamics is balanced with consumers' average activity dynamics. We guess our work's results make it possible to improve contemporary economic instruments, make it more sensitive and more precise.

\section{References}

1. McConnell C.R., Brue S.L. Economics: Principles, Problems, and Policies. Vol.1, 2. $11^{\text {th }}$-edition. Translate in Russian. Vol.2. 1993. P.984. Moscow, Respublika.

2. Svechkin O.N. Math modeling of the commodity market and the solution of inverse problems based on the 
model. // «Ekonomika, statistika i informatika. Vestneyk UMO». - 2009. №3. - S.25-28.

3 . The economic security of Russia / Pod red. Senchagova V.K. 2005. S.896. Moskva, DELO.

4. Novikov D.A., Chkhartishvili A.G. Reflection and control: mathematical models. 2013. P.412. Moskva, Izd. fiziko-matematicheskoj literatury.

5. Economic and national security / Pod red. Goncharenko L.P. 2008. S.543. Moskva, Izd. «Ekonomika».

6. Mednikov V.I. New «Balanced ScoreCard» (BSC) // New approaches in economics and in control: proceedings of III IC (Prague, 14-15 сентября 2013). - Prague, Vedecko vydavatelske centrum «Sociosfera-CZ», 2013. P.118-121.

7. Miropol'sky D.Y. Economic theory and the types of economic systems // «Ekonomika i upravlenie». 2007. - №2. - S. 22-28.

8. Kaplan R.S., Norton D.P. The strategy-oriented organization. 2005. P.416. Moscow, C.J.-s.Co. «OlimpBusiness».

9. Mednikov B.V., Mednikov V.I., Mednikov S.V. Enterprise economy in «market» and in «influence»: materialy mezhdunarodnoj konferencii po ekonomike i obshchestvennym naukam ICESS 2013. T.13. (Melburn, Avstraliya, 21-22 yanvarya 2013). Issledovatelskij institut SShA po informacionnomu inzhiniringu, 2013. S. 150-156.

10. Mednikov V.I. Balances ScoreCard - modification // Trudy WIT po informacionno-kommunikacionnym tehnologiyam, T.49, 2014: materialy mezhdunarodnoj konferen- cii po informacionnym tehnologiyam $\mathrm{i}$ menedzhmentu ITM 2013. (Gonkong, Keitaj, 1-2 noyabrya, 2013g.). - London, WIT Press, 2013. - S.1095-1100.

11. Orehov S.A, Mednikov V.I. The Enterprise Economic Crises Formalization // «Ekonomika, statistika i informatika. VestneykUMO».-2010.№6. - S.96-98.

12. Changes in U.S. Family Finances from 2010 to 2013: Evidence from the survey of consumer Finances. // URL: www.federalreserve.gov / econresdata/scf/scfindex.htm

\section{Литература}

1. Макконнелл К.Р., Брю С.Л., Экономикс. Принципы, проблемы, политика. В 2 Т.: Пер с англ. 11-го изд. 1993. Т. 1. С. 984. Москва, Республика.

2. Свечкин О.Н. Математическое моделирование товарного рынка и решение обратных задач на основе этой модели // «Экономика, статистика и информатика. Вестник УМO». - 2009. - №3. - С. 25-28.

3. Экономическая безопасность России / Под ред. Сенчагова В.К. 2005. С. 896. Москва, ДЕЛО.

4. Новиков Д.А., Чхартишвили А.Г. Рефлексия и управление: математические модели. 2013. С. 412. Москва, Изд. физико-математической литературы.

5. Экономическая и национальная безопасность / Под ред. Гончаренко Л.П. 2008. С. 543. Москва, Изд. «Экономика».

6. Медников В.И. Новая «Balanced ScoreCard» (BSC) // Hoвые подходы в экономике и управлении: материалы III МНПК.
(Prague, 14-15 сентября 2013). Prague, Vedecko vydavatelske centrum «Sociosfera-CZ», 2013. - C. 118-121.

7. Миропольский Д.Ю. Экономическая теория и типы хозяйственных систем // «Экономика и управление». - 2007. - №2. - С. 22-28.

8. Каплан Р.С., Нортон Д.П. Организация, ориентированная на стратегию. 2005. С. 416. Москва, ЗАО «Олимп-Бизнес».

9. Медников Б.В. Медников В.И., Медников С.В. Хозяйственная деятельность предприятия в «рынке» и во «влияниях» // материалы международной конференции по экономике и общественным наукам ICESS 2013. T. 13. (Мельбурн, Австралия, 21-22 января 2013). - Исследовательский институт США по информационному инжинирингу, 2013. - С. 150-156.

10. Медников В.И. Модификация системы управления «Balances ScoreCard» // Труды WIT по информационно-коммуникационным технологиям, Т. 49, 2014: материалы международной конференции по информационным технологиям и менеджменту ITM 2013. (Гонконг, Китай, 1-2 ноября, 2013 г.). - Лондон, WIT Press, 2013. - С. 1095-1100.

11. С.А. Орехов, В.И. Медников. Формализация экономического кризиса предприятия // «Экономика, статистика и информатика. Вестник УМO». - 2010, - №6. - С.96-98.

12. Изменения в финансах американских семей с 2010 по 2013: Данные из обследования финансов потребителей // URL: www.federalreserve.gov / econresdata/scf/scfindex.htm (дата обращения: 04.01.2015). 